Малинаускас Ромуальдас Казимерович

д-р пед. наук, профессор

Аяускас Шарунас

студент

Литовский университет спорта

г. Каунас, Литовская Республика

DOI $10.21661 / \mathrm{r}-554185$

\title{
ОСОБЕННОСТИ ЛИДЕРСКИХ КАЧЕСТВ ТРЕНЕРА
}

\section{ГЛАЗАМИ БАСКЕТБОЛИСТОВ}

Аннотация: иель исследования состоит в том, чтобы изучить особенности лидерских качеств тренера глазами юных и взросльх баскетболистов. Для достижения поставленной цели в качестве методического инструментария был использована шкала лидерства в спорте, разработанная Челладураи. Выяснилось, что юниоры более благосклонно относились к поведению тренера, чем взрослые баскетболисты. Для баскетболистов юниоров характерна более положительная оценка таких лидерских качеств тренера: поведение при проведении инструктажа, социальная поддержка и положительная обратная связь.

Ключевые слова: лидерство, лидерские качества, баскетбол.

Введение. В последнее время большое внимание в научных исследованиях уделяется вопросам лидерства в спорте [1]. Однако недостаточное внимание уделяется исследованиям восприятия спортсменом лидерских качеств тренера [2]. В этой работе будем придерживаться мнения, что лидерство - это способность оказывать влияние на отдельные личности, группы, направляя их усилия на достижение целей [3]. Челладураи [3] разработал специально для спорта многоуровневую модель спортивного лидерства. Эта модель рассматривает лидерство как взаимодействующий процесс. Эффективность спортивного лидерства (тренера) зависит от ситуационных особенностей тренера и членов группы. Эффективное руководство тренера изменяется в зависимости от особенностей спортсменов и ограничительных факторов спортивной ситуации [3]. 
Суть научной проблемы исследования состоит в том, что в научной литературе нет единого мнения относительно особенностей лидерских качеств тренера глазами баскетболистов. Таким образом, целью этого исследования являлось определение различий в оценке лидерских качеств тренера юными и взрослыми баскетболистами.

Методы и организация исследования. Для достижения поставленной цели в качестве методического инструментария была использована, Шкала лидерства в спорте, разработанная Челладураи [3]. Шкала лидерства в спорте измеряет пять параметров лидерского поведения: тренировка (поведение, предполагающее инструктаж); демократичное поведение (стиль принятия решения); диктаторское поведение (стиль принятия решений); социальная поддержка (мотивационные тенденции); положительная обратная связь (мотивационные тенденции).

Шкала лидерства в спорте существует в трех версиях: выяснение, какой тип поведения предпочитают спортсмены, восприятие спортсменом тренерского поведения и восприятие тренерами собственного поведения. Спортсмены в этом исследовании выполнили только оценку спортсменом тренерского поведения. Версия шкалы лидерства в спорте для восприятия спортсменом тренерского поведения содержит сорок пунктов, предваряемых словами: «Мой тренер...», за которым следуют такие утверждения, как «следит за тем, чтобы спортсмены работали...». Каждое утверждение оценивается по шкале с использованием пятибалльной шкалы Лайкерта, выбирая между «никогда - 1» и «всегда - 5». Результаты оценки внутреннего постоянства для опросника по коэффициенту Кронбаха $\alpha$ были весьма высоки, и коэффициент равнялся 0,73 для выборки данного исследования.

В нашу выборку были отобраны 4 команды юных баскетболистов (объем выборки составила группа из 47 юниоров) и 4 команды взрослых баскетболистов, включающих баскетболистов Литовской региональной баскетбольной лиги и баскетболистов Литовской баскетбольной лиги. Выборка взрослых баскетболистов включала 46 игроков. 
Pезультатыл. Применение $t$-критерия Стьюдента показало, что статистически значимые различия двух исследуемых групп при оценке демократичного стиля принятия решения и диктаторского стиля поведения тренера не были обнаружены (Таблица 1). Оказалось, что баскетболисты юниоры оценивают более положительно: поведение тренера при проведении инструктажа тренировки $(\mathrm{t}(91)=1,97 ; \mathrm{p}<0,05)$, социальную поддержку тренера $(\mathrm{t}(91)=1,97 ; \mathrm{p}<0,05)$ и положительную обратную связь $(\mathrm{t}(91)=1,99 ; \mathrm{p}<0,05)$, по сравнению с взрослыми баскетболистами.

Таблица 1

Показатели восприятия спортсменом лидерских качеств тренера

\begin{tabular}{|l|c|c|c|c|}
\hline \multicolumn{1}{|c|}{ Показатели лидерства } & $\begin{array}{c}\text { Юные } \\
\text { баскетболисты, } \\
\mathrm{n}_{1}=47\end{array}$ & $\begin{array}{c}\text { Взрослые } \\
\text { баскетболисты, } \\
\mathrm{n}_{2}=46\end{array}$ & $\begin{array}{c}\mathrm{t}, \\
\mathrm{df}=91\end{array}$ & $\mathrm{p}$ \\
\hline $\begin{array}{l}\text { Тренировка (поведение, предпола- } \\
\text { гающее инструктаж) }\end{array}$ & $3,67 \pm 0,72$ & $3,38 \pm 0,70$ & 1,97 & $\mathrm{p}<0,05$ \\
\hline $\begin{array}{l}\text { Демократичное поведение (стиль } \\
\text { принятия решения) }\end{array}$ & $3,62 \pm 0,81$ & $3,57 \pm 0,78$ & 0,30 & $\mathrm{p}>0,05$ \\
\hline $\begin{array}{l}\text { Диктаторское поведение (стиль } \\
\text { принятия решений) }\end{array}$ & $2,46 \pm 0,76$ & $2,39 \pm 0,74$ & 0,45 & $\mathrm{p}>0,05$ \\
\hline $\begin{array}{l}\text { Социальная поддержка (мотиваци- } \\
\text { онные тенденции) }\end{array}$ & $3,96 \pm 0,75$ & $3,66 \pm 0,72$ & 1,97 & $\mathrm{p}<0,05$ \\
\hline $\begin{array}{l}\text { Положительная обратная связь (мо- } \\
\text { тивационные тенденции) }\end{array}$ & $4,18 \pm 0,81$ & $3,85 \pm 0,79$ & 1,99 & $\mathrm{p}<0,05$ \\
\hline
\end{tabular}

Обсуждение. Следует отметить, что утверждение, что лидерские качества тренера баскетболистами юниорами оцениваются более положительно, чем взрослыми баскетболистами, не противоречит итогам исследований, проведенных другими учеными [4].

Для баскетболистов юниоров более характерна оценка тренера как тренера, который ориентирован на социальную поддержку и заботится о своих спортсменах, старается установить теплые и дружеские отношения с ними. Баскетболисты юниоры оценивают более положительно и то, как тренер обеспечивает положительную обратную связь. В научных исследованиях [3; 4], указывается, что тренер, обращающий большое внимание на обеспечение положительной взаимосвязи, постоянно хвалит и поощряет хорошую работу своих подопечных. 
Заключение. Результаты показали, что восприятие спортсменом тренерского поведения у юниоров достоверно более положительное, чем у взрослых баскетболистов. Для баскетболистов юниоров характерна более положительная оценка таких лидерских качеств тренера: поведение при проведении инструктажа, социальная поддержка и положительная обратная связь. Результаты также показали, что при оценке демократичного стиля принятия решения и диктаторского стиля поведения тренера статистически значимые различия между группами юных и взрослых баскетболистов не были обнаружены.

\section{Список литературы}

1. Федорова О.В. Лидерство в спорте / О.В. Федорова, Е.Н. Фоминова // Педагогика, психология и медико-биологические проблемы физического воспитания и спорта. - 2009. - №10. - С. 258-260.

2. Головин А.А. Лидерство в процессах формирования и социализации спортивных команд / А.А. Головин // Вестник Поволжского института управления. - 2017. - №17. - С. 146-152.

3. Chelladurai P. Leadership in sports: a review / P. Chelladurai // International Journal of Sport Psychology. - 1990. - Vol. 21, №4. - C. 328-354.

4. Yağc1 E. Comparing the Views of Young Football Players and Their Coaches on Leading Behavior Characteristics / E. Yağc1, N. Burgul, Ö. Bozkurt, T. Uluöz // International Journal of Applied Exercise Physiology. - 2021. - №10. - P. 242-250. 